https://doi.org/10.15407/scine16.06.036

\author{
RYBALCHENKO, M.O., SELEGEJ, A.M., GOLOVKO, V.I., \\ SELEGEJ, S.M., and MIRGORODSKAYA, O.S. \\ National Metallurgical Academy of Ukraine, \\ 4, Gagarina Ave., Dnipro, 49600, Ukraine, \\ +380 567453156 , nmetau@nmetau.edu.ua
}

\title{
A MODEL TO CONTROL THE FORMATION OF MULTI-COMPONENT CHARGE PORTIONS ON A BLAST FURNACE CONVEYOR
}

Introduction. Bell-less tops used in the charging area give significantly wider opportunities for regulating and distributing the charge material along the furnace top radius. Moreover, it becomes feasible to develop the methods for gas flow control and these methods shall differ from the conventional ones. One of such methods is introduction of multi-component portions of the charge with a technology based component ratio.

Problem Statement. The bell-less top charging device is not designed for that type of portioning when the charge material mixing is accompanied with a simultaneous shift of one component with respect to other one for a certain set value, while charging. These portions can be formed with the use of computer-aided stock-conveying system, while discharging the material from weighing hoppers into the blast furnace conveyor.

Purpose. This research aims at the development of the structure, the functioning algorithms and the mathematical model for the system to control the formation of multi-component mixed charge batches in order to increase the blast furnace productivity and to reduce the specific coke consumption.

Materials and Methods. In this research, the methods of automatic control theory and artificial intellect for the synthesis of weight neuro-fuzzy controllers within the automatic control system of charge dosage have been used. The developed system designed to control multi-component charge portioning via PC has been tested by means of simulation modelling methods.

Results. There has been developed an algorithm for operating the system for controlling the multi-component mixed charge preparation on the conveyor, given the arrangement of the specified components, their ratios in portions, total volumetric productivity of the conveyor, the variable geometry of the unloaded material, in the connection with the on-line information on the mixing process. The feasibility of the system has been verified by its simulation with the use of standard application tools.

Conclusions. It has been established that the designed control system allows the formation of mixed portions of any composition defined by an operator at a given maximum output of the conveyor and prevents its overload in terms of mass or volume.

Keywords: automation, charge, multi-component charge, control system, dosage, and model.

Bell-less tops used within the charging area [1] has contributed to developing new methods for gas flow control. One of such methods is introduction of multi-component portions of the charge with a technology-based component ratio [2-4].

Citation: Rybalchenko, M.O., Selegej, A.M., Golovko, V.I., Selegej, S.M., and Mirgorodskaya, O.S. A Model to Control the Formation of Multi-Component Charge Portions on a Blast Furnace Conveyor. Sci. innov. 2020. V. 16, no. 6. P. 36-45. https://doi.org/10.15407/scine16.06.036 
The portions are formed by an automatic control system that, depending on the location of the respective weighting hoppers and a given portion, gives the necessary time between the beginning of the next and the end of unload of the previous doses of this portion [5].

The analysis presented in [5] is based on the following suggestions for the procedure of mixed portion preparation:

- spreliminary mixing of pellets with agglomerates before charging to the furnace top;

- spreliminary concentration of pellets in the periphery and axial zones of the furnace top;

- spreliminary iron-bearing materials mixing with coke into separate portions can be combined with separate charge of burden materials.

Provided that the indicated conditions are met, one can improve the layer permeability for gases and the indices of iron-bearing materials reducibility as well as achieve a longer service life for lining and tuyeres, a more stable drive of blast furnace and a higher degree of gas utilization [6, 7].

Research [8] explains the reasonability of charging the principle ingredients (agglomerate, pellets, coke), the unconventional components of the charge (limestone, anthracite, manganese ore, etc.), the screenings of burden materials, and the additives for various purposes in the composition of mixed portions.

Moreover, in the course of the experimental trials with a mixed portion charge, positive results have been achieved as specific consumption of coke decreases $(0.2 \mathrm{~kg}$ of coke is saved per each ton of pig iron) [6].

Further, the analysis on the existing techniques of multi-component portions formation [912] has shown that this problem is still under discussion and is open to successful engineering solutions.

The first attempt to implement the multi-component charge can be assigned to the solution of combining the final elements of certain raw materials portions while loading them on the conveyor [9]. This method was developed to load the charging materials on the conveyor with the time interval as long as it was required for a certain weighing hopper to accumulate a raw material mass that was equal to the mass of the previously charged portion. However, it has a disadvantage for the blast furnace process: the masses and the volumes of portions are not regular, therefore the head of the current portion, which is time marking, does not come to the tail part of the previous portion. Moreover, this method does not enable overlapping of raw materials of various kinds.

In research [11], the method is reported for multicomponent portioning with set locations of the portion on the conveyor, including those charges which consist of three or more different materials (for instance: the ratio of iron ore bearing materials to coke in the charge). The control was carried out per the lead time of the driving portion component beginning with respect to the start of the driven component. Based on this, the time when the discharge mechanism to be released was determined for each weighing bin, the increasing sequence of these values was established and the discharging mechanisms of the weighing hoppers were set off in that sequence. However, this method of multi-component charge forming enabled no opportunities available for making changes in the material consumption during discharging and therefore this led to the conveyor operation with the incomplete capacity on some areas of the burden material portion.

Another method of control described [12] is the control over the mechanisms of the charge delivery to the blast furnace top via forming multi-component mixed portion on the dedicated conveyor. According to the method, the preset locations of the components, the total volumetric capacity of the conveyor and the relation between the components being mixed on the conveyor allow developing the graphs on the components consumption and, in its turn, the control over the discharge mechanisms of the weighing bins is performed according to the graphs. Unfortunately, this does not take into account the geometric parameters of the portion lying on the conveyor and therefore the situation is possible when the central lines of two 
neighboring burden material placements overlap each other and cause conveyor over-loading with the emergency stop of the charge supply.

Considering the mentioned above, the current publication finds it reasonable to address the problem of the system development with the objective to form the desired content of the burden materials portions via the means of the controlled discharge from the hoppers and to provide the maximal effectiveness of the dedicated conveyor without any overloading accidents.

Further, the general requirements for the portions of any structure are said to be minimization of the portion length, which is placed on the conveyor, portion transportation with minimal delays to prevent conveyor overloading followed by burden material coming off on the driven conveyor drum and consequent interruption in the burden materials delivery.

Eventually, it becomes obvious that the necessary condition for the successful multi-component portion formation is the control over the burden materials consumption during discharges of the burdens from the weighing hoppers. Along with this, it is also required to attain the control of the burden materials geometry being placed on the conveyor in order to ensure the desired parameters of the burden materials portions to be charged into the blast furnace.

The use of the radar equipment [13-15] and the availability of the adequate mathematical regularity between the coal consumption and the weighing hopper gate opening [16-22] allow determining how the mixing operation can be controlled when discharging on the blast furnace conveyor.

Provided that the control system for the mixed portions is based on the real-time information on the changes in the discharges of the weighing hoppers, the hopper gate opening time instants, the material coming out of the weighing hoppers and the material geometric parameters, it is possible to reduce the variations both in the length of the gathered portion placed on the conveyor and in the length of its separate parts. In its turn, this permits decreasing in variations in some of the production parameters, for instance, the mass of the principle portion and the mass of agglomerate-pellet mixture.

Further, in order to ensure the mixed portions of burden materials to possess the given placement, the desired amounts and the preset proportions of the ingredients while they are discharged onto the conveyor, the formation of the mixed portions is to be carried out with the control over the gate opening mechanisms intended for regulating the cross-sections of the bin scales opening for the discharge.

With this publication, we report on the developments of the structure and the algorithm, the mathematical model for the control system of multi-component burden materials formation on the conveyor with respect to the preset arrangement of the components, their ratios and portions, total conveyor capacity, variable geometry of the raw materials to be discharged and with the observance of the interconnection with the real-time information on the mixing process. The formation of the mixed portion in our case is carried out as suggested above by the mechanisms of the gate, which controls the hole cross-section of the bin scales during the time when the materials are coming on the conveyor. The conveyor speed is constant and is $2 \mathrm{~m} / \mathrm{s}$. The control over the discharge is performed via the preset time of burden materials unloading on the dedicated portion area, the amount of the materials to be discharged on this area and the rate of their consumption. The maximal volumetric capacity of the conveyor is also taken into account.

The block diagram of the newly developed system for mixed portions formation is illustrated in Fig. 1 and describes the control over the three weighing hoppers, the rest of the weighting hoppers are controlled in the similar way.

As Fig. 1 illustrates, the following elements are introduced for each weighting hopper into the automatic control system for burden materials dosage:

- signal to determine the moment for the discharge mechanism switching on; 


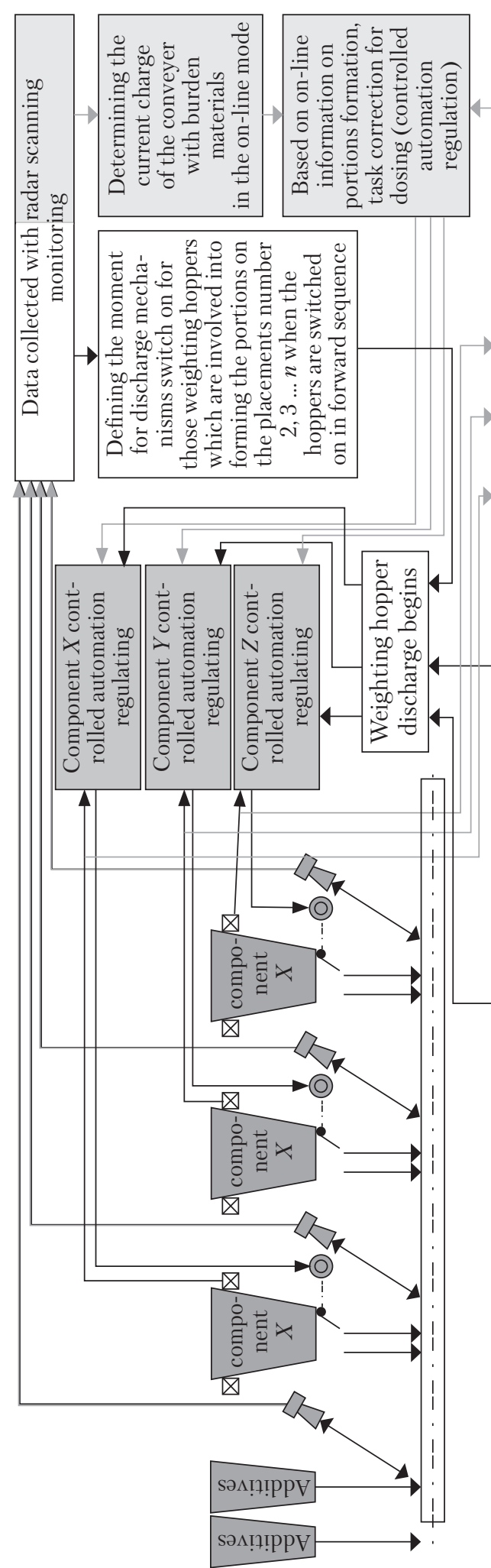

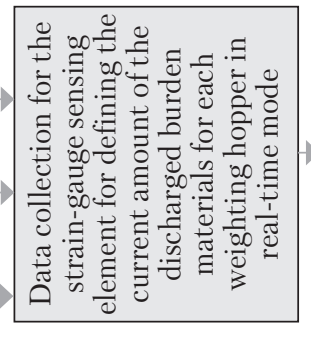

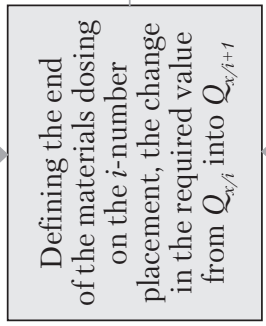

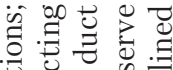

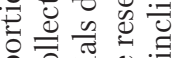

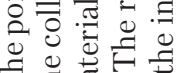

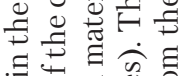

$\exists \underset{0}{ \pm} \Xi$

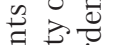

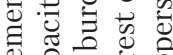

สิ ส

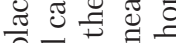

뉴ㅇㅝㅠ.

范

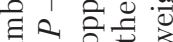

$\Xi$

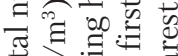

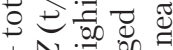

$N \cdot \infty$

$\therefore \vec{\Xi}, 0$

$\approx$ च प

is

-

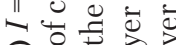

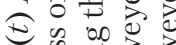

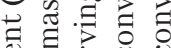

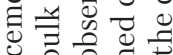

$\pi$ 年

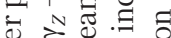

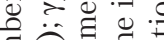

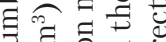

ㄱ. 용

그.

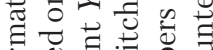

0 我运

원 는,

要

0

00000

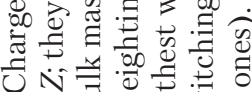

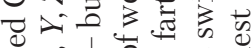

远 1000

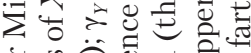

एँ

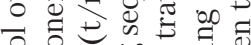

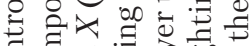

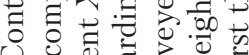
U.

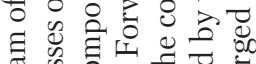
क

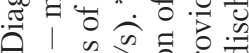
a no 0 范

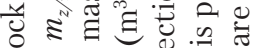

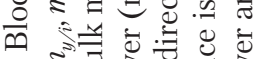
$\therefore \equiv 3$ 过 过 


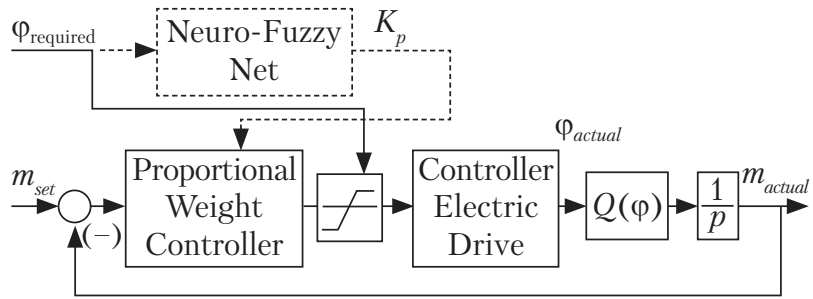

Fig. 2. The Structural Pattern of the Automatic Regulation System for the Charge Materials Dosage.

$m_{\text {set }}$ is the set value of the mass to be discharged from the weighing hopper; mactual is actual mass; $Q(\varphi)$ is mathematical model of burden materials rate supply per the angle of weighing hopper gate opening; $\varphi_{\text {required }}$ is required value of the angle of weighing hopper gate opening; $\varphi_{\text {actual }}$ is angle value of weighing hopper gate opening; $1 / p$ is integrator

- information on the required consumption of the component within each placement (the required consumption is corrected with the observance of the on-line information on the mixing processes, received from strain-gauge sensing elements and radars);

- total mass value to be discharged from the weighing hopper when the portion formation.

According to the real-time data information obtained from the radar sensors of the charge level, the current discharge of the burdens on the conveyor is determined in the real-time mode and the correction of the automatic regulation system for portioning is carried out as being based on the real-time information of portion formation.

The specific feature of the charge dosage regulation system to be operated within the control system for multi-component portion is that there are the limits imposed on the controller exit, they are related to the changes in the required demand for the component depending on what placement the discharge is to be. The structural pattern of the automatic regulation system for the charge material dosage is shown in Fig. 2 (diagram without a continuous graph).

Within the blast furnace charging equipment, the asynchronous drives with AP-83-12 short-circuited rotors are employed for controlling the burden materials release. The vector control is chosen for the system to control the asynchronous dri-
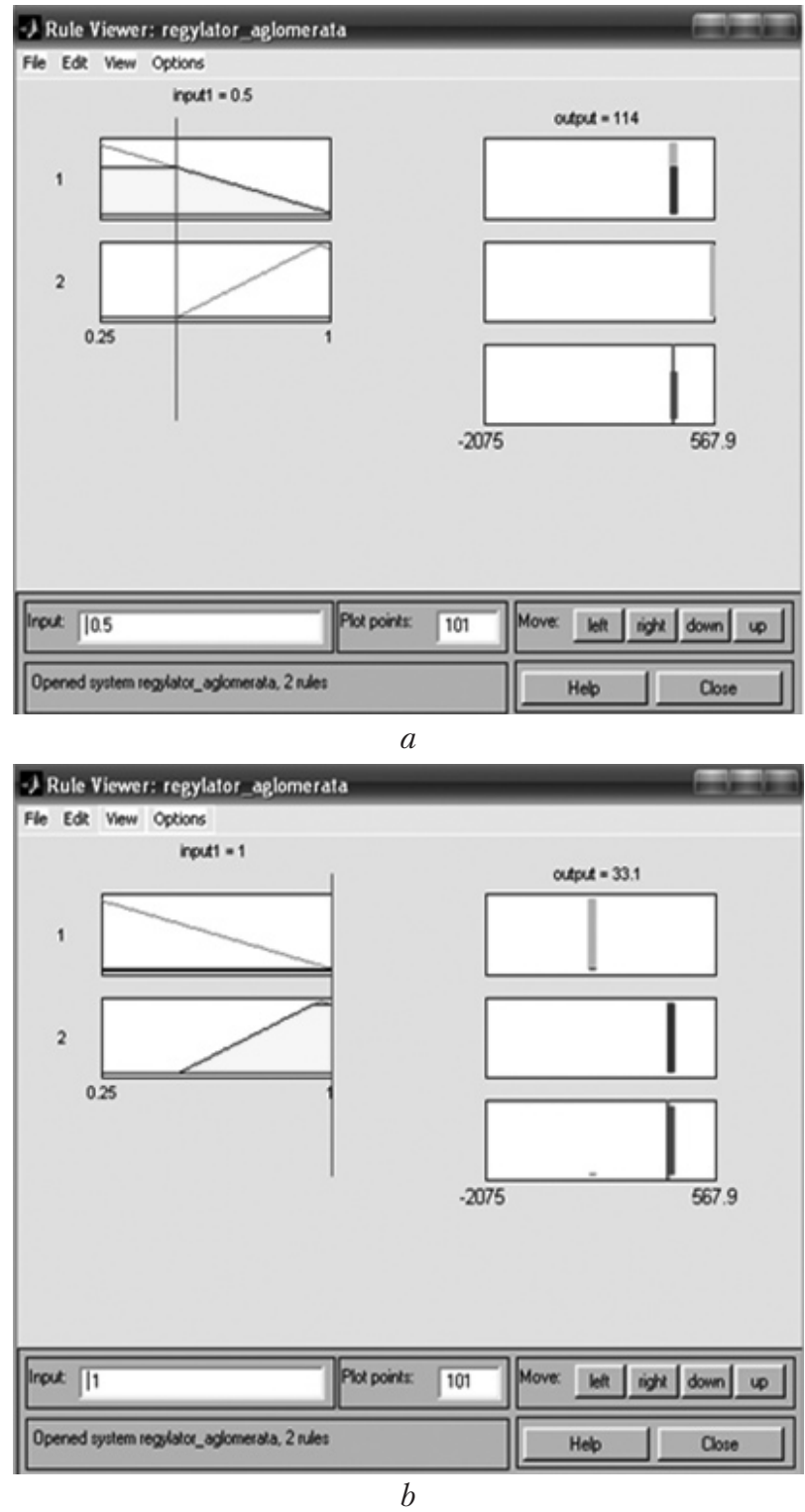

Fig. 3. Rule Viewer for the Fuzzy Input

ves [23, 24]. Research [25] reports on the simulation results for the control system over the asynchronous drive to operate the weighing hopper gate.

In order to provide the performance of automatic regulation for dozing, the use of an adaptive neuro-fuzzy weight controller is necessary. At this, the input variable is the required angle of a weighing hopper gate opening at $i$-placement while the output variable is the proportionality coef- 

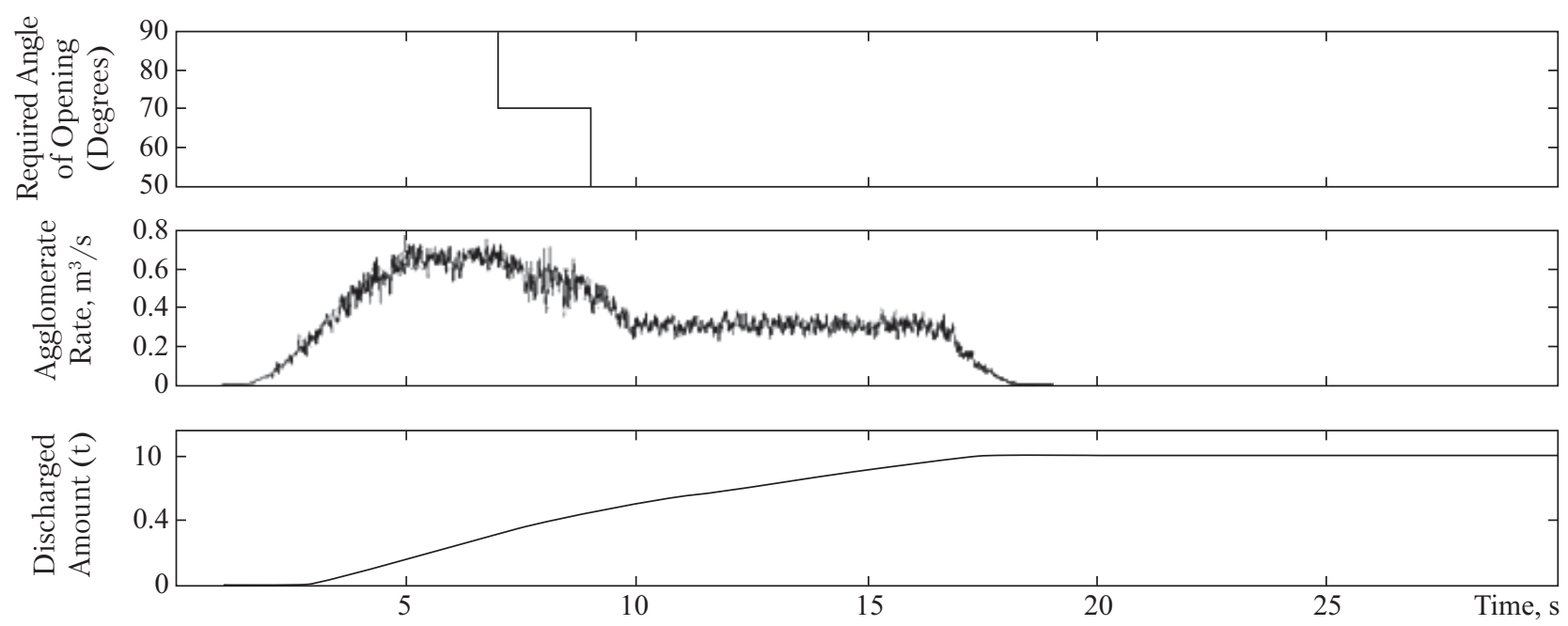

Fig. 4. Simulation Results

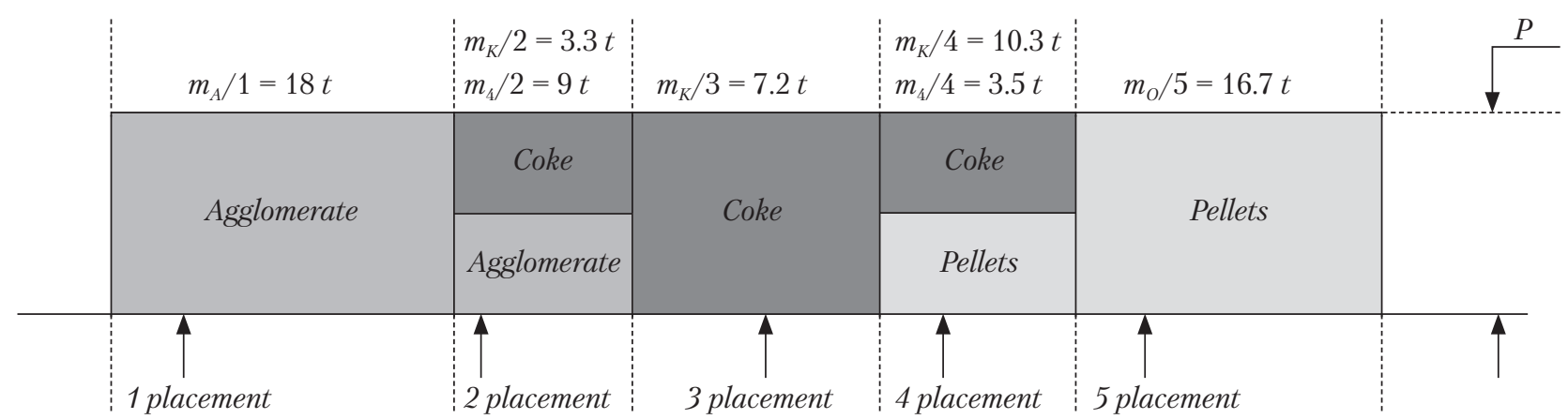

Fig. 5. The Structure of the Set Portion

ficient $\left(K_{p}\right)$ and adaptive neuro-fuzzy proportional controller.

The structural scheme of the adaptive automatic regulation system with neuro-fuzzy weight controller is shown in Fig. 2 (diagram with a continuous graph).

For the sake of the information collection on the object behavior and cause-and-effect relations between the required angle of the gate opening on $i$-placement and the settings of the proportional controller, the simulation has been conducted for the dosage operations and the obtained results permit determining the proportional controller settings as dependent on the required angle of the gate opening.

Table 1 shows the results of the parameter calculations for the proportional controller of the agglomerate dosage system at various limitations imposed on the control signal of the controller.

The parameters of the weight controller for pellets and coke were calculated by the same scheme.

The data obtained from thereof have been applied as the training set for the neuro-fuzzy net (Adaptive Network Based Fuzzy Inference System, ANFIS). The latter acts in accordance to the Sugeno algorithm and is widely used for the controllers of the fuzzy systems of automatic regulation.

In order to analyze the adequacy of the developed system in terms of parameter output by the proportional controller, we applied the rule viewer of the rule database (refer to Fig. 3). The values obtained via the program assistance were input and output parameters (relative value of 


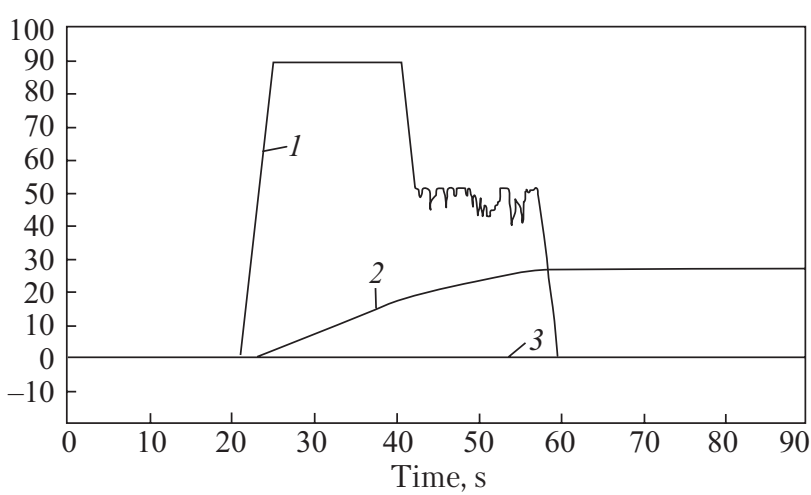

Fig. 6. A1 Left Weighing Hopper at Operation: 1- Angle of Weighing Hopper Gate Opening, degrees; 2 - Discharged Mass, t (27 t); 3 - Material Charge to the Conveyor, $\mathrm{m}^{3} / \mathrm{s}$

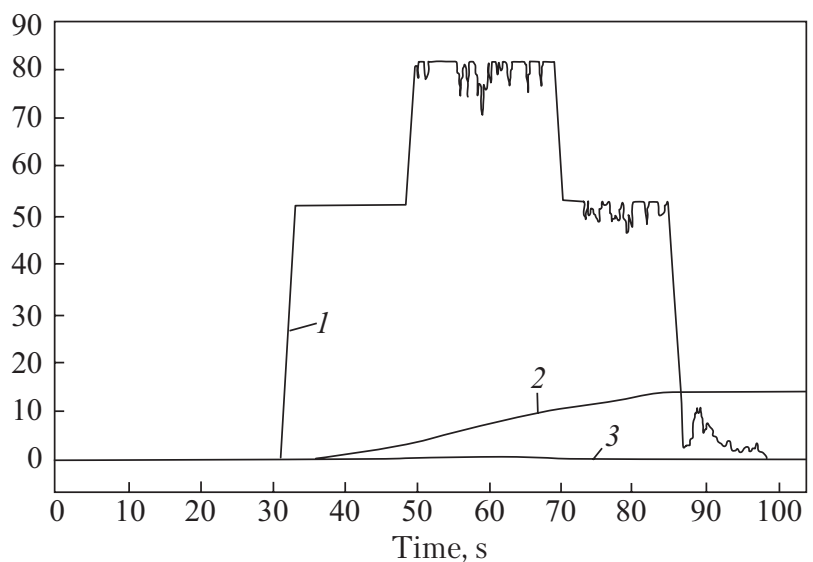

Fig. 7. K2 Left Weighing Hopper at Operation: 1- Angle of Weighing Hopper Gate Opening, degrees; 2 - Discharged Mass, t (14 t); 3 - Conveyer Material Charge, $\mathrm{m}^{3} / \mathrm{s}$

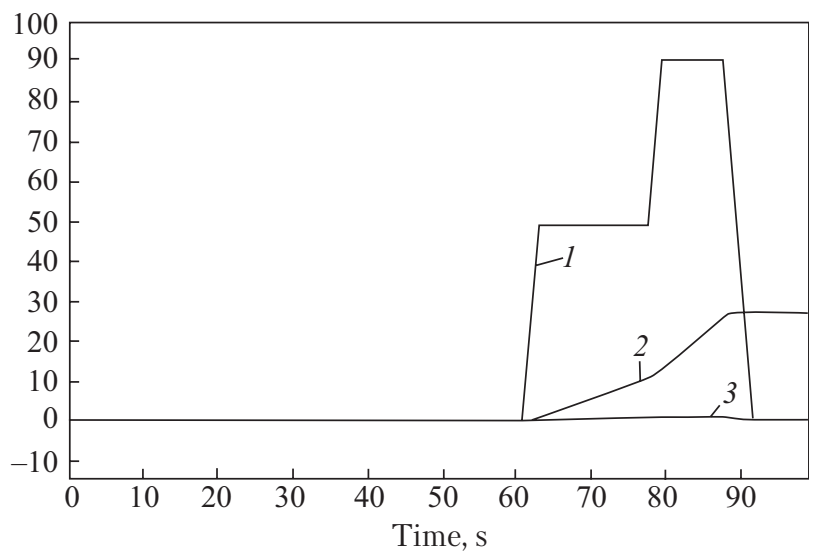

Fig. 8. O1 Left Weighing Hopper at Operation: 1 - Angle of Weighing Hopper Gate Opening, degrees; 2 - Discharged Mass, $\mathrm{t}(27 \mathrm{t}) ; 3$ - Conveyor Material Charge, $\mathrm{m}^{3} / \mathrm{s}$ an angle opening $\varphi_{\text {required }} / \varphi_{\text {max }}=0.5 \rightarrow K_{p}=114 \mathrm{il}-$ lustrated in Fig. 3, $a ; \varphi_{\text {required }} / \varphi_{\max }=1 \rightarrow K_{p}=33.14$ refer to Fig. 3, $b$ ), they coincided with the values obtained by testing. This brought the evidence that the developed neuro-fuzzy net was adequate.

This taught neuro-fuzzy net has been applied in adaptive automatic regulation of the burden materials supply.

The dedicated simulation modelling has been performed in order to check the effectiveness of the neuro-fuzzy net performance. The results of the simulation for the agglomerate dosage regulation system which incorporated the limitations of the controlling action are shown in Fig. 4 (at the reference time of $\varphi_{\text {required }}=90^{\circ}$; at the reference time of $t=7 \mathrm{~s}$ and $\varphi_{\text {required }}=70^{\circ}$; at the reference time of $t=9 \mathrm{~s} \varphi_{\text {required }}=50^{\circ}$ ).

The graphs analyzed with respect to the transition processes within the system have evidenced that the agglomerate dosage precision is high (the error is $\pm 0.1 \%)$. Note that the occasional placement on the other surface has been taken into account, along with the limitations imposed on the weight controller output.

The neuro-fuzzy weight controllers within the automatic regulations for pellets dosage and coke dosage are synthesized in the identical way.

The adequacy of the designed system of control over the formation of charge mixed portions has been assessed by means of the simulation study

Table 1. The Calculated Parameters of the Proportion Controller at Various Angles for Weighing Hopper Gate Opening

\begin{tabular}{|c|c|c|}
\hline $\begin{array}{c}\text { Required } \\
\text { Angle of } \\
\text { Opening, } \\
\varphi_{\text {required }}\end{array}$ & $\begin{array}{c}\text { Relative Value } \\
\text { for the Required Angle } \\
\text { of Opening, } \\
\varphi_{\text {required }} / \varphi_{\max }\end{array}$ & $\begin{array}{c}\text { Proportionality } \\
\text { Coefficient of } \\
\text { Agglomerate Weight } \\
\text { Controller, } K_{p}\end{array}$ \\
\hline 90 & 1 & 33.14 \\
67.5 & 0.75 & 51.25 \\
45 & 0.5 & 114 \\
22.5 & 0.25 & 590 \\
\hline
\end{tabular}

" $\varphi_{\max }$ - the maximal angle values for weighing hopper gate opening, is equal to $90^{\circ}$. 


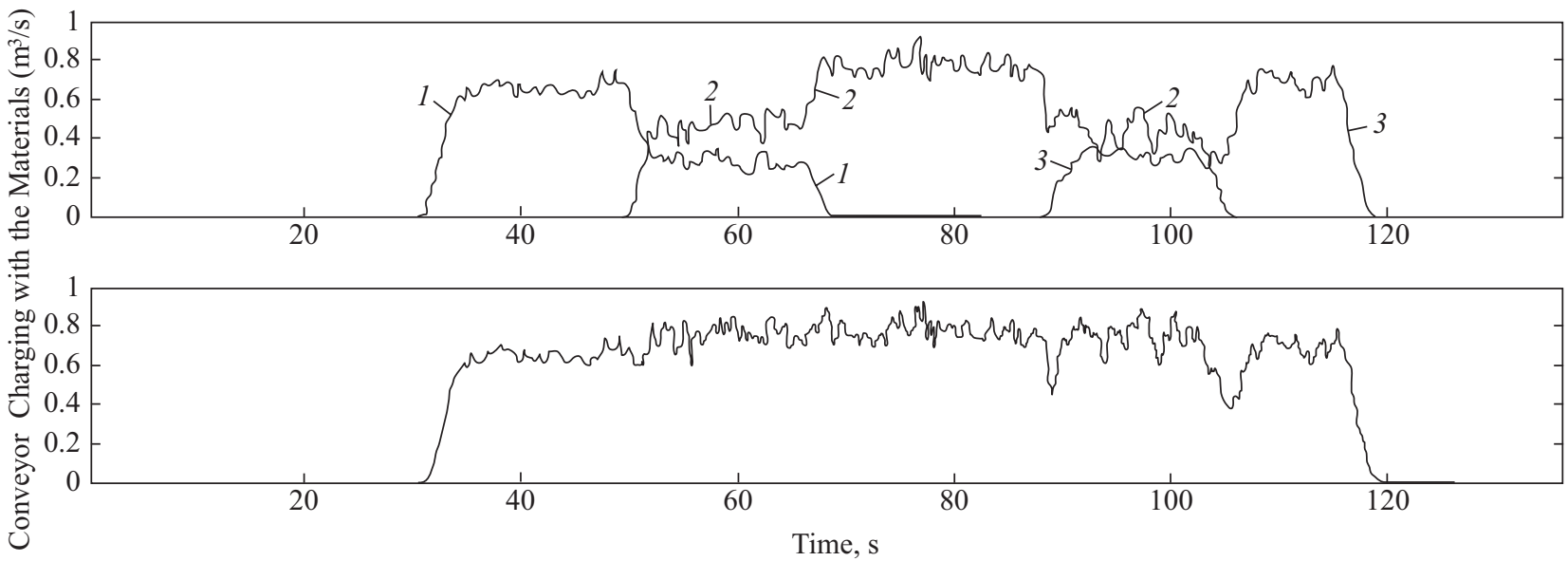

Fig. 9. Conveyor Charging with the Materials: 1 - Changes in Agglomerate Consumption; 2 - Changes in Coke Consumption; 3 - Changes in Consumption of Pellets

based on the algorithm for simulating the behavior and the interaction of the system elements.

Before simulating per the set program for the blast furnace charge, the multi-component mixed portions were determined in the form of the placements following each other on the conveyor. Within these placements the amount and the ratios of the components were constant. Thus, the initial data for the simulation were the component masses on the placements, the bulk masses of charge materials and the volumetric capacity of the conveyor.

The weighing hoppers were also involved in the process of multi-component formation.

The simulation results of the portion formation structure are shown in Fig. 5.

The following parameters were set: $m_{A} / 1=18 t$ is the agglomerate mass in the first placement; $m_{A} / 2=9 t$ is the agglomerate mass on the second placement, $m_{K} / 2=3.3 t$ is the coke mass on the second placement of the portion, $m_{K} / 3=7.2 t$ is the coke mass on the third placement, $m_{K} / 4=3.5 t$ is the coke mass on the fourth placement, $m_{0} / 4=$ $=10.3 t$ is the pellets mass on the fourth placement, $m_{O} / 5=16.7 t$ is the pellets mass on the fifth placement, $P=0.8 \mathrm{~m}^{3} / \mathrm{s}$ is the conveyor volumetric capacity, $\gamma_{K}=0.45 \mathrm{t} / \mathrm{m}^{3}$ is the coke bulk mass, $\gamma_{A}=1.6 \mathrm{t} / \mathrm{m}^{3}$ is the agglomerate bulk mass, $\gamma_{\mathrm{O}}=$ $=2.1 \mathrm{t} / \mathrm{m}^{3}$ is the pellet bulk mass.
The following weighing bins were chosen for the discharge: K2 left, O1 left и A1 left.

The simulation results are shown in Figs. 6-9.

The analysis of the techniques of multi-component portions formation on the conveyor for the blast furnace charging has shown that the mentioned problem still requires a proper engineering solution. The necessary condition for solving this problem is measures to control and regulate the burden materials consumption when they are discharged out from the weighing hoppers. Along with the controlled release of the burden materials, there is also the necessity of the control over burden materials geometry on the conveyor in order to provide the required parameters of the burden portion.

The structure, the operation algorithms, and the mathematical model have been developed for exercising control over the formation of multicomponent charge on the conveyer, given the preset arrangement of the discharged burden materials on the conveyor, their portions and ratios and the variability of their geometry in relation to the online information on the mixing operations.

The use of the adaptive neuro-fuzzy controller within the automatic regulation has enabled us to provide a high accuracy of the burden materials dosage (the simulation results have shown that the possible error is $\pm 0.1 \%$ ). 
The adequacy of the designed control system for forming the mixed portions of the burden materials has been performed on the grounds of the simulation modelling which has been assessed by operation algorism to simulate the behavior of the system components and their interaction.

Having analyzed the graphs obtained in the simulation process for various charge portions one can conclude that the designed system for controlling mixed portion formation allows realizing the formation of multi-component portions consisting of whatever amount of materials, given the specified arrangement of the components and their ratio in the portion, the variable geometry of the bulk material unloaded, the total volumetric capacity of the conveyor in conjunction with operational information about the mixing process, which makes it possible to form portions of charge materials according to any structure given the maximum performance of the conveyor with the prevention of its overload in terms of weight (volume).

\section{REFERENCES}

1. Bolshakov, V. I. (2004). Contemporary charging equipment and monitoring systems for blast furnace reconstruction. Metallurgical and Mining Industry, 5, 96-100 [in Russian].

2. Loginov, V. I., Berin, A. L., Solomatin, S. M. (1977). The influence of iron ore material mixed with coke on gas dynamic conditions and technical and economic performance of a blast furnace. Steel in Translation, 5, 391-394 [in Russian].

3. Loginov, V. I., Musienko, S. M., Berin, A. L. (1984). Charging iron ore raw materials mixed with coke. Metallurgical and Mining Industry, 3, 10-12 [in Russian].

4. Loginov, V. I., Musienko, S. M., Voronkov, D. V. (1987). Blast furnace performance at skip charging iron ore raw materials along with coke. Steel in Translation, 12, 7-12 [in Russian].

5. Bolshakov, V. I. (1990). Theory and practice of blast furnace charging. Moscow [in Russian].

6. Bolshakov, V. I., Ivancha, N. G., Muravieva, I. G., Vishniakov, V. I. (2012). The study and industrial testing for charging multicomponent mixed portions, consisting of iron ore raw materials and coke. Collection of scientific works of Z. I. Nekrasov Iron E E Steel Institute of NAS of Ukraine "Fundamental and applied problems of ferrous metallurgy", 18, 53-67 [in Russian].

7. Bolshakov, V. I., Gladkova, N. A., Ivancha, N. G., Shutylev, F. M., Porubova, T. P. (2006). Interconnection of smelt indicators under operation with multicomponent burden materials charge. Collection of scientific works of Z. I. Nekrasov Iron $\mathcal{E}$ Steel Institute of NAS of Ukraine: "Fundamental and Applied Problems of Ferrous Metallurgy", 13, 15-26 [in Russian].

8. Bolshakov, V. I., Ivancha, N. G., Muravieva, I. G., Vishniakov, V. I. Technological explanation on effectiveness of multicomponent mixed charge application in blast furnace practice. Collection of scientific works of Z. I. Nekrasov Iron E Steel Institute of NAS of Ukraine "Fundamental and Applied Problems of Ferrous Metallurgy", 25, 103-122 [in Russian].

9. A. s. 694446. MPK S 21 V 7/20. Method for feeding charge materials into a blast furnace. A. V. Prazdnikov, E. Ya. Klotsman, F. M. Shutylev, V. I. Golovko, I. P. Denisik. No. 2380955; publ. 30.10.1979, Bjul. No. 40.

10. Bolshakov, V. I., Ivancha, N. G. (2002). Preparing mixed portions of burden materials on the conveyer for the blast furnace. Metallurgical and Mining Industry, 6, 79-83.

11. A. s. 1049549. MPK S 21 V 7/20. Method of controlling mechanisms of conveyor charge feeding of blast furnaces. G. D. Zolotnickaia, M. M. Frenkel, Burgutin, B. G. Garbuz, E. Ya. Klotsman, V. I. Golovko, A. S. Gurov. No. 3358183; pripritet izobretenya 26.11.1981; publ. 23.10.1983, Bjul. No. 39.

12. Patent of the Russian Federation № 2016068, MPK S 21 V 7/20. Porkh, V. I. The Technique for controlling the mechanisms of burden materials supply for blast furnace practice [in Russian].

13. Viktorov, V. A., Lunkin, B. V., Sovlukov, A. S. (1989). Radio wave methods to measure the parameters of technological processes. Moscow [in Russian].

14. Golovko, V. I., Kukushkin, O. N., Mihajlovskij, N. V. (1998). Opportunities of microwave methods of measurement for monitoring technological processes in metallurgy. Collection of scientific and technical papers: "Electronics technology", 1(471), 14-17 [in Russian].

15. Rybalchenko, M. A., Golovko, V. I., Verhovskaia, A. A. (2011, April). Radar impulse spectrum analysis for on-line determination of the metallurgical materials level. Collection of articles based on the materials of the international forum of juniour scientists "The problems of natural resources management", 48-50. St. Petersburg [in Russian].

16. Shternlikht, D. V. (1984). Hydraulics. Moscow [in Russian]. 
17. Kiriia, R. V., Maksiutenko, V. Ju., Braginets D. D., Mostovoi, B. I. (2008). Back to the problem of bulky materials discharge from the bin with the slot opening. Geo-Technical Mechanics "Geo-Technical Mechanics", 80, 351-362 [in Russian].

18. Kiriia, R. V., Braginets D. D., Mostovoi, B. I. (2009). Bulky materials discharge from the bin with the lateral slot opening. Collection of Research Papers of the National Mining University, 32, 114-122 [in Russian].

19. Kiriia, R. V. (2003). Concerning the factor of internal losses at bulky material movement on the elements of belt conveyer transfer groups. Geo-Technical Mechanics, 41, 159-167 [in Russian].

20. Kiriia, R. V., Maksutenko, V. Yu., Titschenko, T. F., Mostovoi, B. I. (2009). Concerning interaction of bulky material with the cover plate. Geo-Technical Mechanics “Geo-Technical Mechanics”, 83, 246-252 [in Russian].

21. Kiriia, R. V., Rybalchenko, M. A., Mostovoi, B. I. (2012). Bulky material discharge from the bin with automatic lateral gate. Collection of Research Papers of the National Mining University, 37, 217-224 [in Russian].

22. Rybalchenko, M. A., Ivatschenko, V. P., Golovko, V. I., Kiriia, R. V., Papanov, H. A. (2012). Verification on the performance correctness for the mathematical model to describe the dependence between bulky material consumption and gate opening angle. Scientific Bulletin «Modern problems of Metallurgy», XV(15), 25-35 [in Russian].

23. Vinogradov, A. B. (2008). Vector control of alternating current electric drives. Ivanovo [in Russian].

24. Rudakov, V. V., Stoljarov, I. M., Dartau, V. A. (1987). Asynchronous electric drives with vector control. Leningrad [in Russian].

25. Rybalchenko, M. A., Golovko, V. I., Verhovskaya, A. A., Papanov, G. A. (2014). Simulation of Vector Control Asynchronous Electric Motor Gate Weight Funnel of System Serve of Charge Blast Furnace. Mining Journal of Kryvyi Rih National University, 98, 123-130 [in Russian].

Received 14.05.19

Revised 23.07.19

Accepted 07.11.19

М.О. Рибальченко, А.М. Селегей, В.І. Головко,

С.М. Селегей, О.С. Миргородська

Національна металургійна академія України, просп. Гагаріна, 4, Дніпро, 49600, Україна, +380567453156, nmetau@nmetau.edu.ua

\section{МОДЕЛЬ УПРАВЛІННЯ ФОРМУВАННЯМ БАГАТОКОМПОНЕНТНИХ ПОРЦИЙ ШИХТИ НА ДОМЕННОМУ КОНВЕСРІ}

Вступ. Застосування безконусних завантажувальних пристроїв значно розширило технологічні можливості регулювання і розподілу шихти по радіусу колошника доменних печей. При цьому виникла можливість розробки методів управління газовим потоком, одним з яких є завантаження в піч багатокомпонентних порцій шихти з технологічно обгрунтованим співвідношенням компонентів.

Проблематика. Безконусний завантажувальний пристрій не призначено для формування порцій шихти шляхом змішування з одночасним зсувом в процесі завантаження одного виду матеріалу щодо іншого на задану величину. Реалізувати формування таких порцій можна за допомогою ЕОМ системи шихтоподачі в процесі розвантаження матеріалів з вагових воронок на доменний конвеєр.

Мета. Розробка структури, алгоритмів функціонування та математичної моделі системи управління формуванням багатокомпонентних (змішаних) порцій шихти для підвищення продуктивності доменної печі та зменшення питомої витрати коксу.

Матеріали і методи. Використано методи теорії автоматичного управління і штучного інтелекту для синтезу нейронечітких регуляторів ваги для системи автоматичного регулювання дозування шихти. Застосовано методи імітаційного моделювання для тестування розробленої системи управління формування багатокомпонентних порцій шихти на ЕОМ.

Результати. Розроблено алгоритм функціонування та виконано моделювання роботи системи управління формуванням змішаних порцій з урахуванням заданого розташування компонентів, їхнього співвідношення в порції, сумарної об'ємної продуктивності конвеєра, змінної геометрії сипучого матеріалу, що розвантажується з вагової воронки, у взаємозв'язку з оперативною інформацією про процес змішування.

Висновки. Розроблена система управління дозволяє сформувати порції шихтових матеріалів відповідно до будь-якої структури при заданій максимальній продуктивності конвеєра, виключаючи його перевантаження за масою (об’ємом).

Ключові слова: автоматизація, шихта, багатокомпонентні порції, система управління, дозування, модель. 